\title{
The nuclear lamina during human spermiogenesis
}

\author{
Michael Mitchell \\ From 1st French-Italian meeting on laminopathies and other nuclear envelope-related diseases \\ Marseille, France. 15-16 January 2015
}

The nuclear lamina takes centre stage during spermiogenesis, the post-meiotic phase of spermatogenesis, when haploid round spermatids differentiate into spermatozoa: the acrosome and flagellum develop at opposite nuclear poles, the nucleus elongates and, as the nuclear histones are replaced with protamines, the chromatin condenses, to produce the highly compacted pyriform nucleus of the mature spermatozoa. In rodent spermatids, the nuclear lamina contains lamin B1 and lamin B3 a specific isoform of lamin B2 with a shortened rod domain, and A-type lamins are absent $[1,2]$, but nothing is known about the structure of the nuclear lamina during human spermiogenesis. We are studying the nuclear lamina during human spermiogenesis. We have shown that the human nuclear lamina contains lamin B1 and, distinct from rodents, lamin B2. We also described a transcript potentially encoding a human lamin B3 that, like its mouse counterpart [3], induces severe nuclear deformation when expressed in HeLa cells [4]. In human, lamin B1 and B2 localise to the nuclear periphery in spermatids except in the region covered by the acrosome. They are seen to recede to the posterior pole of the nucleus as the spermatids progress through spermiogenesis. Lamin B1 was observed on $30-40 \%$ of ejaculated spermatozoa, while lamin B2 was not detected. The percentage of B1-labelled spermatozoa dropped at least 6-fold when spermatozoa with normal head density were selected, indicating that lamin B1 labels immature spermatozoa lacking a fully compacted nucleus, and may therefore be a marker of poor sperm quality. The comparison of the human nuclear lamina with that of the mouse suggests that lamin B1 and B3 have critical roles during mammalian spermiogenesis.

Correspondence: michael.mitchell@univ-amu.fr

Aix Marseille Université, INSERM, GMGF UMR_S 910 13385, Marseille, France
Published: 11 November 2015

\section{References}

1. Schutz W, Alsheimer M, Ollinger R, Benavente R: Nuclear envelope remodeling during mouse spermiogenesis: postmeiotic expression and redistribution of germline lamin B3. Experimental cell research 2005, 307(2):285-91.

2. Vester B, Smith A, Krohne G, Benavente R: Presence of a nuclear lamina in pachytene spermatocytes of the rat. Journal of cell science 1993, 104(Pt 2):557-63.

3. Schutz W, Benavente R, Alsheimer M: Dynamic properties of germ linespecific lamin B3: the role of the shortened rod domain. European journal of cell biology 2005, 84(7):649-62.

4. Elkhatib R, Longepied G, Paci M, Achard V, Grillo JM, Levy N, et al: Nuclear envelope remodelling during human spermiogenesis involves somatic B-type lamins and a spermatid-specific B3 lamin isoform. Molecular human reproduction 2015, 21(3):225-36.

doi:10.1186/1750-1172-10-S2-O22

Cite this article as: Mitchell: The nuclear lamina during human spermiogenesis. Orphanet Journal of Rare Diseases 2015 10(Suppl 2):O22.

Submit your next manuscript to BioMed Central and take full advantage of:

- Convenient online submission

- Thorough peer review

- No space constraints or color figure charges

- Immediate publication on acceptance

- Inclusion in PubMed, CAS, Scopus and Google Scholar

- Research which is freely available for redistribution
() Biomed Central

(c) 2015 Mitchell This is an Open Access article distributed under the terms of the Creative Commons Attribution License (http:// creativecommons.org/licenses/by/4.0), which permits unrestricted use, distribution, and reproduction in any medium, provided the original work is properly cited. The Creative Commons Public Domain Dedication waiver (http://creativecommons.org/publicdomain/ zero/1.0/) applies to the data made available in this article, unless otherwise stated. 